\title{
Phosphopeptides and soluble calcium in the small intestine of rats given a casein diet
}

\author{
BY YEON SOOK LEE, T. NOGUCHI AND H. NAITO \\ Department of Agricultural Chemistry, The University of Tokyo, Bunkyo-Ku, \\ Tokyo I I 3, Japan
}

(Received 4 July 1979 - Accepted 9 January 1980)

I. Semi-synthetic diets containing $200 \mathrm{~g}$ protein $/ \mathrm{kg}$ were meal-fed for $\mathrm{I} \cdot \mathrm{s} \mathrm{h}$ to groups of rats. The contents of the whole small intestinal tract were collected and the amount of soluble calcium was determined.

2. In the rats given $200 \mathrm{~g}$ casein $/ \mathrm{kg}$ diet, formation of a fraction containing macrophosphopeptide in the small intestine was confirmed by gelfiltration of the intestinal contents on Sephadex G-25. However, this macrophosphopeptide fraction was not found when casein alone was fed.

3. In the intestinal contents at $2.5 \mathrm{~h}$ after ingestion, the amounts of both soluble $\mathrm{Ca}$ and phosphorus were significantly higher in rats fed the casein diet than in those fed diets containing egg albumin, isolated soyabean protein or an amino acid mixture. However, the amount of insoluble $\mathrm{Ca}$ was least in rats fed the casein diet.

It is widely recognized that calcium is efficiently utilized from milk and milk products by man and a variety of other animal species.

Among factors contained in milk, lactose has been extensively investigated as a possible agent which enhances $\mathrm{Ca}$ absorption from the small intestinal tract (Lengemann, 1959; Wasserman, I964; Armbrecht \& Wasserman, 1976).

On the other hand, Mellander (I947) showed that phosphopeptides formed by proteolytic digestion of casein are relatively resistant to further proteolytic breakdown by digestive enzymes, and also showed that these phosphopeptides bind to form a soluble complex with $\mathrm{Ca}$ ions. From the latter results, Mellander (1950; 1963) suggested that these substances enhance $\mathrm{Ca}$ absorption and utilization by infants, with no evidence of the formation in vivo of phosphopeptides, solubilization of $\mathrm{Ca}$ in the small intestinal lumen, or enhancement of Ca absorption in the presence of phosphopeptides.

Naito et al. (1972) reported the first evidence of the formation of phosphopeptides in the intestinal contents of rats shortly after receiving a casein-containing diet.

The main aims of the present work were to extend previous studies (Naito et al. 1972; Naito \& Suzuki, 1974; Naito \& Lee, 1977) and to determine the extent of phosphopeptide formation after a meal containing casein. Results showed a higher concentration of soluble $\mathrm{Ca}$ in the small intestinal tract after a meal containing casein than with the other protein sources tested.

\section{MATERIALS AND METHODS}

\section{Animals and diets}

Male rats of Wistar strain weighing $120-160 \mathrm{~g}$, were housed in individual wire cages in a room controlled at $22 \pm 2^{\circ}$ with a relative humidity of $60 \pm 5 \%$. The animals for meal-feeding experiments were trained to consume a diet containing $200 \mathrm{~g}$ casein $/ \mathrm{kg}$ (basal diet) within $\mathrm{I} .5 \mathrm{~h}$ by decreasing daily the period of access to food. The training period was at least 2 weeks. The rats were given free access to water at all times.

The composition of the experimental diets is shown in Table $\mathrm{I}$. All experimental diets contained polyethylene glycol (PEG, molecular weight 4000 ) as a non-absorbed indicator.

Two experiments were carried out as follows: 
Table I. Composition of experimental diets $(\mathrm{g} / \mathrm{kg})$

$\begin{array}{lccc}\text { Ingredients } & \begin{array}{c}\text { Casein } \\ \text { (Basal) }\end{array} & \begin{array}{c}\text { Basal without } \\ \text { fat }\end{array} & \begin{array}{c}\text { Basal without } \\ \text { starch }\end{array} \\ \text { Casein* } & 200 & 200 & 200 \\ \text { Maize starch } & 680 & 725 & - \\ \text { Soya-bean oil } & 45 & - & 300 \\ \text { Cellulose powder } & 5 & 5 & 430 \\ \text { Mineral mixture } \dagger & 40 & 40 & 40 \\ \text { Vitamin mixture } \ddagger & 8 & 8 & 8 \\ \text { Choline chloride } & 2 & 2 & 2 \\ \text { Polyethylene glycol } & 20 & 20 & 20\end{array}$

* In Expt 2 an amino acid mixture, egg albumin, or isolated soya-bean protein was substituted for casein; the other dietary components being the same as the casein diet. The composition of the amino acid mixture, which simulated that of casein, was as given by Ahrens et al. (1966).

$\dagger$ The mineral mixture based on the pattern of Rogers \& Harper (1965) contained the following ( $\mathrm{g} / \mathrm{kg}$ mixture): $\mathrm{CaCO}_{3} 292 \cdot 9, \mathrm{CaHPO}_{4} \cdot 2 \mathrm{H}_{2} \mathrm{O} 4_{4} \cdot 3, \mathrm{KH}_{2} \mathrm{PO}_{4} 343 \cdot \mathrm{I}, \mathrm{NaCl} 250 \cdot 6, \mathrm{MgSO}_{4} \cdot 7 \mathrm{H}_{2} \mathrm{O} 99 \cdot 8$, ferric citrate. $6 \mathrm{H}_{2} \mathrm{O} 6 \cdot 23, \mathrm{CuSO}_{4} \cdot 5 \mathrm{H}_{2} \mathrm{O}$ 1.56, $\mathrm{MnSO}_{4} \cdot \mathrm{H}_{2} \mathrm{O}_{\mathrm{I}} \cdot 2 \mathrm{I}, \mathrm{ZnCl}_{2} 0.2, \mathrm{KI} 0.005,\left(\mathrm{NH}_{4}\right)_{6} \mathrm{MO}_{7} \mathrm{O}_{24} \cdot 4 \mathrm{H}_{2} \mathrm{O} 0.025$.

$\$$ Vitamin mixture was prepared according to the National Academy of Sciences (I972) with starch to adjust the total weight.

Expt 1 . Dietary factors affecting the formation of casein phosphopeptides (CPP) in the small intestinal tract

Thirty six rats were used.

Expt I $a$. Effect of feeding pattern on CPP formation was examined using eight rats. CPP formation in the small intestine of rats given the basal diet by meal-feeding was compared with those fed the same diet ad lib. The period of access to food in the former group was restricted to between $10 \cdot 00$ and $\mathrm{I} I \cdot 30$ hours. Rats were killed $\mathrm{I} h$ after withdrawal of the diets. The latter group was fed the basal diet ad lib. for $10 \mathrm{~d}$ and was killed at 24.00 hours. The profiles of filtration on Sephadex G-25 gel and some properties of macropeptide fraction were examined as will be described later.

Expt $1 b$. The formation of CPP after a meal was examined as a function of digestion time. Sixteen rats were meal-fed the basal diet for $1.5 \mathrm{~h}$ as Expt $\mathrm{I} a$, and killed at intervals of I, 4, I 2 and $24 \mathrm{~h}$ after withdrawal of the diet. Intestinal contents were obtained and offered to analysis as will be described later.

Expt i $c$. Effect of diets on CPP formation was studied. Twelve rats were meal-fed the basal diet without starch or fat or casein alone for $1.5 \mathrm{~h}$ as Expt $1 a$. Rats were killed $\mathrm{i} \mathrm{h}$ after withdrawal of the diets. Expts $\mathrm{I} b$ and $c$ were performed on the same day using rats randomly selected from the same lot of rats. Therefore, the values of the ' $I$ ' group of Expt $\mathrm{i} b$ were employed as basal diet group in Expt I $c$. Intestinal contents of rats were examined as will be described later.

Expt 2. Effect of diets on the amount of soluble $\mathrm{Ca}$, soluble phosphorus and insoluble $\mathrm{Ca}$ in the small intestinal contents

Rats were divided into four groups of four each. They were meal-fed diets containing different protein sources; casein (Hammarsten; Merck), egg albumin (Merck), isolated soya-bean protein (Fuji Oil Co., Tokyo) and an amino acid mixture simulating casein described by Ahrens et al. (1966) except that serine was used instead of phosphoserine. Diets were fed for $\mathrm{I} \cdot 5 \mathrm{~h}$ during the $2 \mathrm{~d}$ before killing. Rats were killed $\mathrm{i} \mathrm{h}$ after withdrawal of the diet on the last day. 


\section{Preparation of the intestinal contents for analysis}

All experimental rats were anaesthetized by intraperitoneal injection of sodium pentobarbital $(50 \mathrm{mg} / \mathrm{kg}$ body-weight). In Expt $\mathrm{I}$, the whole small intestinal contents, from proximal duodenum to distal ileum, were thoroughly flushed out with ice-cold saline $(9 \mathrm{~g}$ sodium chloride/l), and made up to a known volume with the same solution. Portions of the contents were immediately analysed for PEG and total proteolytic enzyme activity.

The remaining sample was homogenized using a Polytron homogenizer with ice-cold trichloroacetic acid (TCA) solution (100 g/l). The supernatant fraction obtained by centrifugation of the homogenate at $9000 \mathrm{~g}$ for $20 \mathrm{~min}$, was neutralized with I M-sodium hydroxide to $\mathrm{pH} 5$ and evaporated to dryness under reduced pressure at a temperature below $40^{\circ}$.

In Expt 2, the alimentary tract was ligated at three positions in the small intestine; i.e. directly below the stomach, in the middle of the smal! intestine and just above the caecum. The entire tract was then removed and divided into two halves, the upper and lower parts, which corresponded to the duodeno-jejunum (proximal $400-450 \mathrm{~mm}$ ) and ileum (distal $350-400 \mathrm{~mm}$ ) respectively. The upper and lower intestinal contents were flushed out with ice-cold saline, homogenized and centrifuged to obtain the soluble and the insoluble fraction, and then stored at $-20^{\circ}$ until analysed.

\section{Fractionation on Sephadex gel}

Sephadex G-25 in a fine bead form was used for fractionation of macropeptides and other lower molecular weight components. The samples $(3 \mathrm{ml})$ were applied to the column $(27 \times 400 \mathrm{~mm})$ and eluted at a rate of $60 \mathrm{ml} / \mathrm{h}$ with $0.05 \mathrm{M}$-acetic acid. The void volume was measured with Blue Dextran 2000 (Pharmacia). Sixty $5 \mathrm{ml}$ fractions were collected and divided into two portions, shown in Figs I, 2 and 3, containing large peptides and lower molecular weight components respectively.

\section{Analyses}

The amount of PEG in the intestinal contents was determined by the turbidimetric method of Hydén (1955). Total proteolytic enzyme activities were estimated spectrophotometrically as described by Rick (1977), using casein as the substrate. The $\alpha$-amino-nitrogen in fractions $I$ and 2 (Tables 2, 3 and 4) was determined using the ninhydrin method of Rosen (1957) after hydrolysis with $6 \mathrm{M}$-hydrochloric acid at $110^{\circ}$ for $18 \mathrm{~h}$ using leucine as a standard. The soluble and insoluble $\mathrm{Ca}$ contents were determined after wet ashing with concentrated acid using an atomic absorption spectrophotometer (Shimadzu, AA-640-12; Shimadzu Seisakusho Ltd, Kyoto, Japan). Before analysis the sample was diluted with lanthanum chloride solution ( $10 \mathrm{~g} / \mathrm{l})$. Soluble $\mathrm{P}$ was determined by the method of Chen et al. (1956), after perchloric acid oxidation. All determinations were performed in duplicate. Differences between the group given the casein diet and the other dietary groups were analysed statistically by Student's $t$ test (Snedecor \& Cochran, 1967).

\section{RESULTS}

\section{Expt 1. Dietary factors affecting the formation of CPP in the small intestinal tract}

Expt I $a$. Fig. I shows the elution profiles obtained from Sephadex G-25 filtrate of the TCA-soluble fraction of the intestinal contents of rats fed the basal diet ad lib. or for ${ }^{1} \cdot 5 \mathrm{~h}$. The faster peak, fraction $\mathrm{I}$, contained large peptides and organic phosphate. The latter was estimated from the difference between values obtained before and after perchloric acid digestion. The slower peak, fraction 2 , was constituted mostly by free amino acids and 


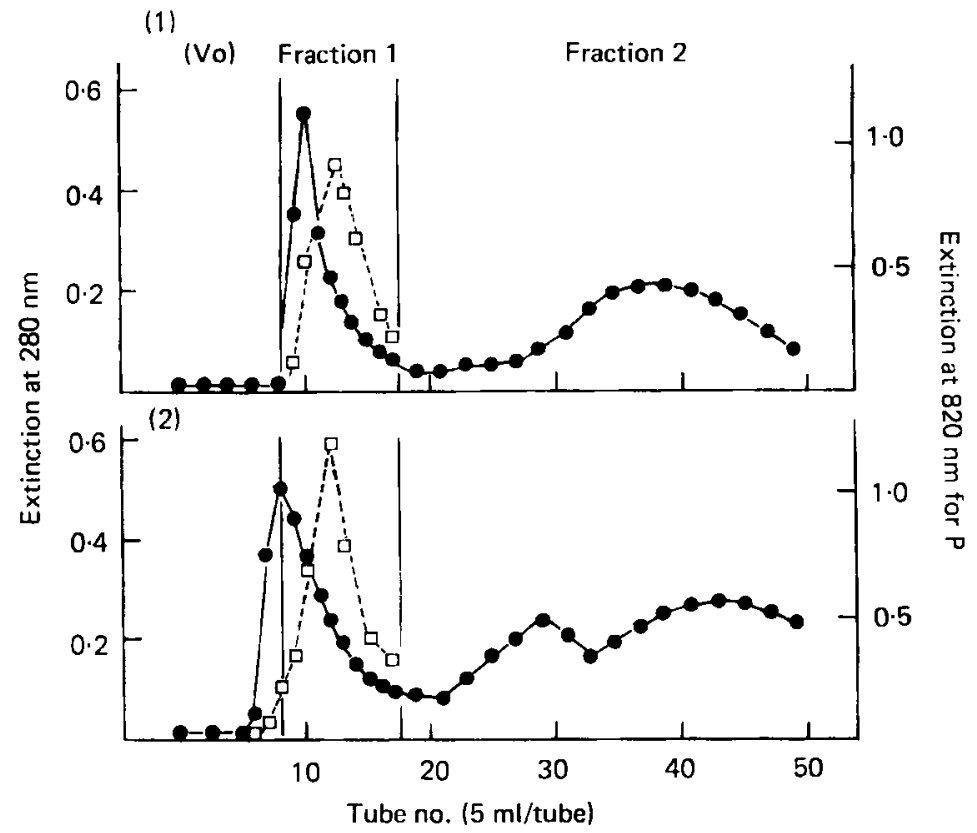

Fig. I. Typical gel filtration profile on Sephadex G-25 of the trichloroacetic acid-soluble fractions of the intestinal contents of rats given $200 \mathrm{~g}$ casein/ $\mathrm{kg}$ (basal) diet ad lib. (1) or meal-fed (2). - - Extinction at $280 \mathrm{~nm} ; \square-\square$, organic phosphorus; Vo, void volume; fraction I, large peptides; fraction 2, lower molecular weight components. For details of procedures, see p. 459 .

Table 2. Expt 1 a. Nitrogen and phosphorus contents of fractions obtained from the small intestinal contents of rats fed $200 \mathrm{~g}$ casein/ $\mathrm{kg}$ (basal) diet ad lib. or at $2.5 \mathrm{~h}$ after ingestion of the basal diet by meal-feeding

(Mean values with their standard errors for four rats/group)

\begin{tabular}{|c|c|c|c|c|}
\hline \multirow[b]{2}{*}{ Feeding pattern } & \multicolumn{2}{|c|}{ Meal-fed } & \multicolumn{2}{|c|}{ Ad lib. } \\
\hline & Mean & SE & Mean & SE \\
\hline $\begin{array}{l}\text { Fraction I } \dagger \\
\alpha \text {-amino-N }(\mu \mathrm{mol}) \\
\text { Phosphorus }(\mu \mathrm{mol}) \\
\text { N:P }\end{array}$ & $\begin{array}{r}92.3 \\
10.6 \\
8.8\end{array}$ & $\begin{array}{r}10.0 \\
1.1 \\
0.6\end{array}$ & $\begin{array}{r}95.6 \\
6.4 \\
15.0\end{array}$ & $\begin{array}{l}9 \cdot 7 \\
0 \cdot 2^{* *} \\
1 \cdot 7^{*}\end{array}$ \\
\hline $\begin{array}{l}\text { Fraction } 2_{+}^{+} \\
\quad \alpha \text {-amino-N }(\mu \mathrm{mol})\end{array}$ & $346 \cdot 0$ & $37^{\circ} \cdot 2$ & $169 \cdot 3$ & $33^{1 *}$ \\
\hline
\end{tabular}

possibly some small peptides (Zebrowska, 1968). Table 2 shows some properties of fractions $I$ and 2. The fraction containing macrophosphopeptides was found in the rats meal-fed the basal diet as well as in those rats given the basal diet ad lib. Higher $\mathrm{N}: \mathrm{P}$ ratio in the ad lib. group might be a reflection of further digestion of CPP along with dephosphorylation.

Expt $\mathrm{i} b$. Changes in the elution profiles with the period of intestinal digestion after feeding the basal diet are depicted in Fig. 2. The macropeptides were found at 2.5 and $5.5 \mathrm{~h}$ after meal-feeding but not at 13.5 and $25.5 \mathrm{~h}$. These results confirm previous observations (Naito et al. 1972). As has been confirmed previously, the peak eluted at the position of void volume (Vo) was not due to protein contaminants (Naito et al. 1972) but to large peptides. The $\alpha$-amino-N and total P contents of fraction $I$ are shown in Table 3 . At 2.5 

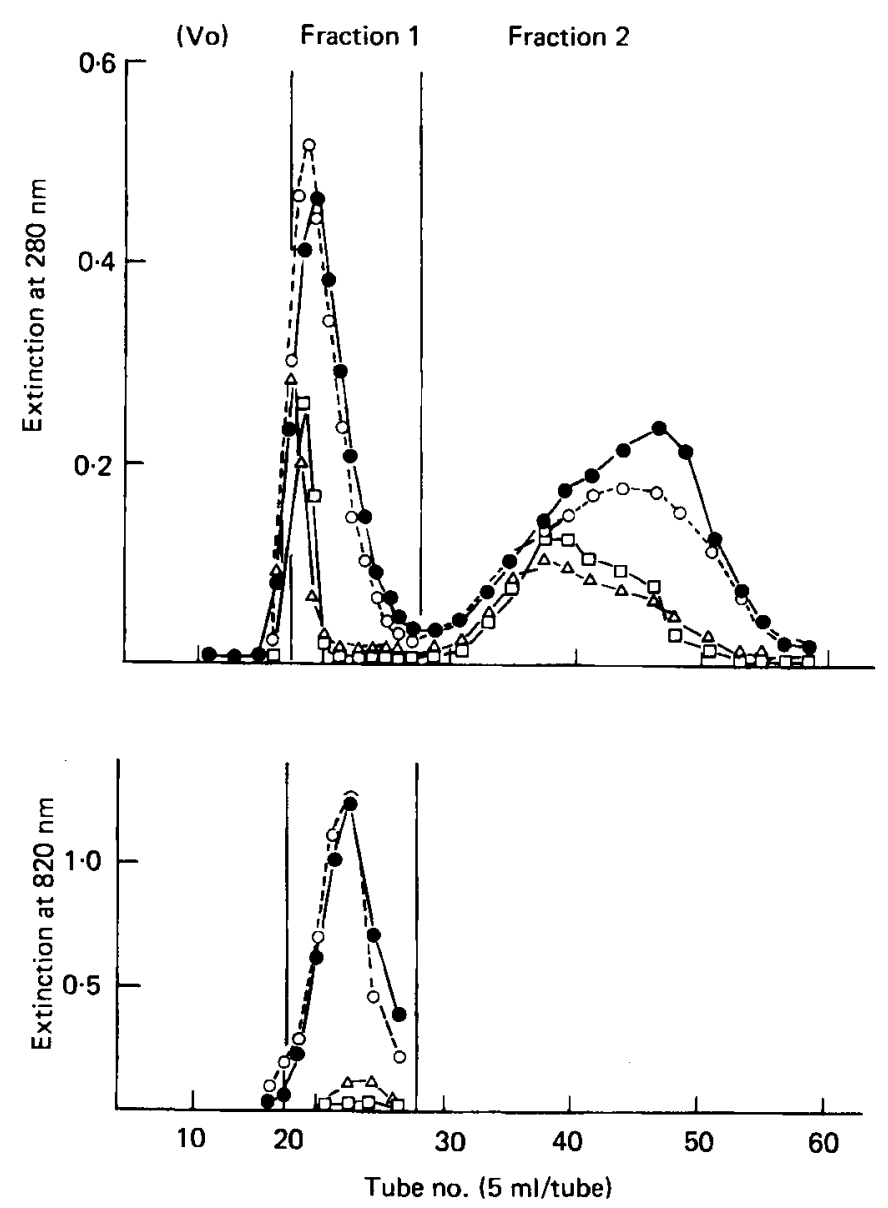

Fig. 2. Changes in the elution patterns with period after meal for intestinal contents after ingestion of $200 \mathrm{~g}$ casein $/ \mathrm{kg}$ (basal) diet; $2.5 \mathrm{~h}(--\mathrm{C}), 5.5 \mathrm{~h}(\mathrm{C}-\mathrm{C}), 13.5 \mathrm{~h}(\triangle-\triangle), 25.5 \mathrm{~h}$ $(\square-\square)$. Vo, void volume; fraction 1 , large peptides; fraction 2 , lower molecular weight components.

and $5.5 \mathrm{~h}$ after meal-feeding, intestinal content of PEG was high, which suggests that phosphopeptides are formed during digestion of casein.

Expt I c. Fig 3 shows the elution profiles obtained from Sephadex G-25 filtrate of the TCA-soluble fraction of the intestinal contents of rats at $2.5 \mathrm{~h}$ after ingestion of the basal diet without fat or starch, or casein alone. The fraction containing macrophosphopeptides was found in the rats meal-fed the basal diet without fat or starch but not in the rats given casein alone. Table 4 shows food intake and total proteolytic enzyme activity and the amount of PEG in the small intestinal contents of rats meal-fed the basal diet, or the basal diet without starch or fat, or casein alone. Some properties of fractions $I$ and 2 are also shown. At $2.5 \mathrm{~h}$ a noticeable amount of large peptides rich in $\mathrm{P}$ was found in all rats given the diet containing $200 \mathrm{~g}$ casein $/ \mathrm{kg}$, which corresponded to between 20 and $35 \%$ of the total TCA-soluble $\alpha$-amino-N. However, the amount of these components was small in rats receiving the basal diet without starch. Only slight amounts of macropeptides with no organic $P$ were found in the rats given casein alone. Total proteolytic activity in rats receiving casein alone was two to three times higher than that in rats given the diet 
Table 3. Expt I b. Food intake, total proteolytic enzyme activities and the amount of polyethylene glycol (PEG) in the small intestinal contents, and nitrogen and phosphorus contents of fractions obtained from the small intestinal contents of rats at $2.5,5.5,13.5$, and $25.5 \mathrm{~h}$ after ingestion of $200 \mathrm{~g}$ casein $/ \mathrm{kg}$ (basal) diet*

(Mean values with their standard errors for four rats/group. Rats were meal-fed the basal diet for $\mathrm{I} \cdot 5 \mathrm{~h}$, and killed at $\mathrm{I}, 4, \mathrm{I} 2$ and $24 \mathrm{~h}$ after withdrawal of the diet)

Period after meal ...

\begin{tabular}{|c|c|c|c|c|c|c|c|}
\hline \multicolumn{2}{|c|}{2.5} & \multicolumn{2}{|c|}{5.5} & \multicolumn{2}{|c|}{13.5} & \multicolumn{2}{|c|}{$25 \cdot 5$} \\
\hline Mean & SE & Mean & SE & Mean & SE & Mean & SE \\
\hline $5 I$ & 2 & 49 & 2 & 52 & 5 & 54 & 2 \\
\hline $21 \cdot 0$ & $2 \cdot 0^{a}$ & 19.0 & $\mathrm{I} \cdot 3^{a}$ & 16.0 & $2 \cdot 6^{a b}$ & $11 \cdot 4$ & $1 \cdot 3^{b}$ \\
\hline $30 \cdot 5$ & $1 \cdot 9^{n}$ & $29 \cdot 9$ & $3 \cdot 5^{a}$ & $7 \cdot 4$ & $4^{\cdot 8^{b}}$ & 0.3 & $0.1^{b}$ \\
\hline$\pi 19.5$ & $12 \cdot 3^{\alpha}$ & 120.0 & $14^{\cdot} 8^{a}$ & $44 \cdot 8$ & $5 \cdot 9^{b}$ & $4 I \cdot 4$ & $7 \cdot 8^{b}$ \\
\hline 10.9 & $I \cdot 5^{a}$ & 10.4 & $2 \cdot 0^{a}$ & 0.8 & $0.6^{b}$ & 0.3 & $0.0^{b}$ \\
\hline II $\cdot 2$ & $0.7^{a}$ & I I 8 & $0.7^{a}$ & I 74.4 & $60 \cdot 0^{b}$ & $144 \cdot 6$ & $24 \cdot 3^{b}$ \\
\hline $288 \cdot 7$ & $57 \cdot 6^{a}$ & $22 I \cdot 5$ & $39 \cdot 6^{a}$ & 101.9 & $29 \cdot I^{b}$ & 104.9 & $22 \cdot 0^{b}$ \\
\hline
\end{tabular}

Food intake (g/kg body-wt)

Proteolytic activity (TU' $\left.{ }^{\text {ens }}\right) \S$

PEG (mg)

Fraction i $\dagger$

$\alpha$-amino-N $(\mu \mathrm{mol})$

Phosphorus ( $\mu \mathrm{mol})$

$N: P$

Fraction $2 \ddagger$

$\alpha$-amino-N $(\mu \mathrm{mol})$

ontal row with different superscripts are significantly different $(P<0.05)$.

$a, b$, Values within the same horizontal
* For details, see p. 457 and Table I.

† Macropeptides including phosphopeptides.

$\ddagger$ Lower molecular weight components.

§ One mg crystalline trypsin shows 6 TU $^{\text {can }}$ (Rick, 1977).

containing $200 \mathrm{~g}$ casein $/ \mathrm{kg}$. There was no significant difference between the basal diet and the basal diet without fat in the quantity of PEG at $2.5 \mathrm{~h}$ after food intake. However, the PEG level was significantly lower in rats given the basal diet without starch than that in the other two groups of rats.

\section{Expt 2. Effect of diets on the amounts of soluble $\mathrm{Ca}, \mathrm{P}$ and insoluble $\mathrm{Ca}$ in the small intestinal contents}

Table 5 shows food intake and the amount of PEG in the small intestinal contents of rats at $2.5 \mathrm{~h}$ after ingestion of diets containing casein, amino acid mixture, egg albumin or soya-bean protein as the protein source. Although food intake was lower in the amino acid diet group and in the egg albumin diet group than in the casein diet group, there was no significant difference between the casein, amino acid, egg albumin and soya-bean protein diets in the quantity of PEG at $2.5 \mathrm{~h}$ after food intake. Therefore, the passage of the diet into the small intestinal lumen did not seem to differ among the groups irrespective of dietary conditions or of the amount ingested. At $2.5 \mathrm{~h}$ after feeding, more than $85 \%$ of the PEG in the small intestine was found in the lower portion.

As shown in Table 6, the amount of soluble $\mathrm{Ca}$ in the small intestinal contents of rats given the casein diet was approximately twice that found in the other groups of rats. Further, more than $75 \%$ of total soluble $\mathrm{Ca}$ in the small intestinal contents was found in the lower portion. This means that $45 \%$ of dietary $\mathrm{Ca}$ in the lower portion of the small intestine of the casein-fed rats must be soluble. Whereas, less than $30 \%$ of $\mathrm{Ca}$ of dietary origin was soluble in the other groups of rats. The latter results were supported by determination of the insoluble $\mathrm{Ca}$ in the small intestine.

Results in Table 7 show a lower amount of insoluble $\mathrm{Ca}$ in the small intestinal contents of rats given the casein diet. 

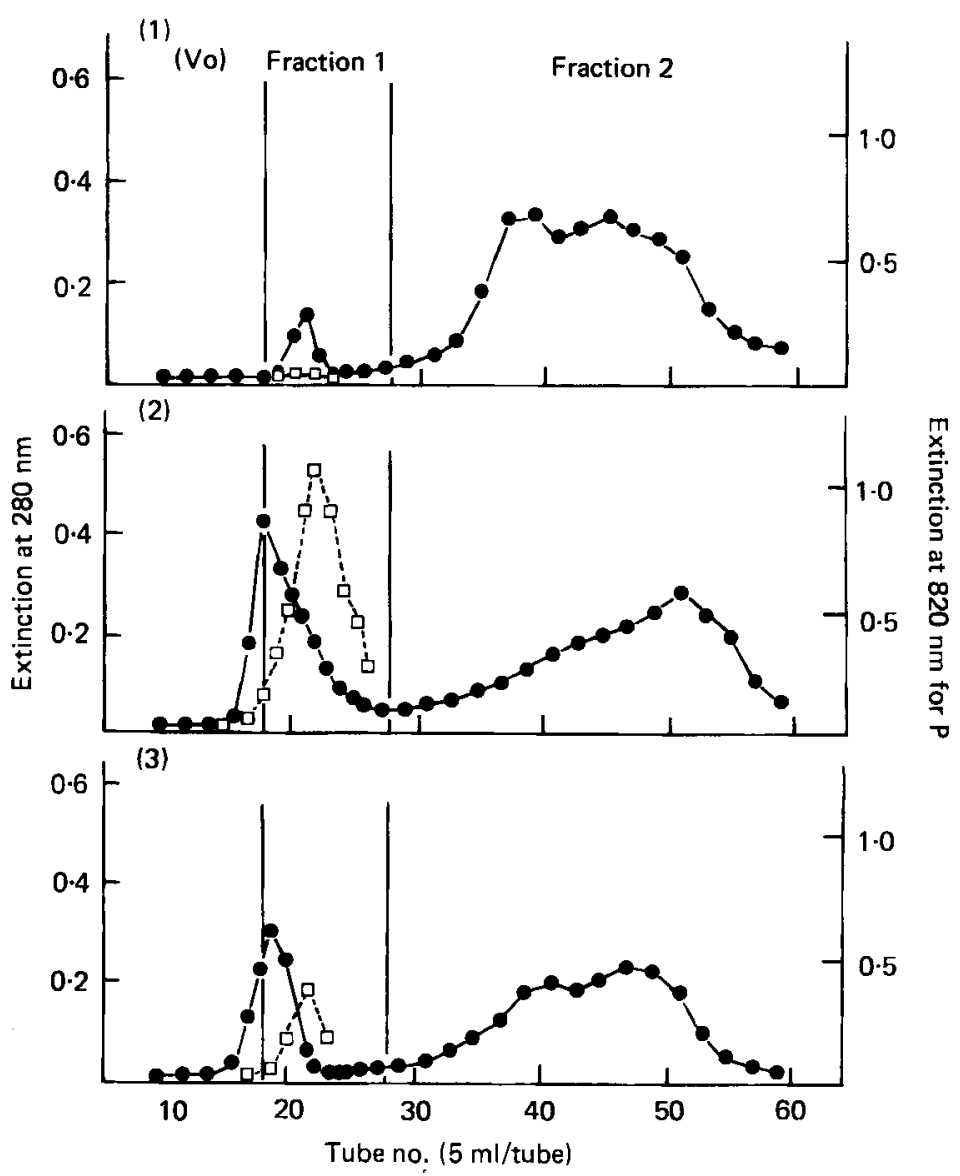

Fig. 3. Typical gel filtration profile on Sephadex G-25 of the trichloroacetic acid-soluble fractions of the intestinal contents of rats given casein alone (I), basal diet without fat (2), or basal diet without starch (3). - - Extinction at $280 \mathrm{~nm} ; \square \longrightarrow \square$, organic phosphorus; Vo, void volume; fraction I, large peptides; fraction 2, lower molecular weight components.

Soluble $P$ levels of the intestinal contents and their relation to dietary $P$ are shown in Table 8 . In the rats given the casein diet, soluble $P$ was three to six times greater than that in the rats given the diets containing amino acids, egg albumin or soya-bean protein. These results suggested that an insoluble complex of $\mathrm{Ca}$ and $\mathrm{P}$ is formed mainly in the lower portion of the small intestine.

\section{DISCUSSION}

In the present investigation we have demonstrated that CPP formation is directly involved in the process of casein digestion. As shown in Table 3, between I and $4 \mathrm{~h}$ after feeding of the casein diet, approximately $0.3 \mathrm{I} \mathrm{mg}$ ( $\mathrm{I} \circ \mu \mathrm{mol}$ ) $\mathrm{P}$ was found in the macropeptides fraction. The $P$ content of whole casein is $8.3 \mathrm{mg} / \mathrm{g}$ (Bennich et al. 1957). Therefore the amount of $P$ derived from dietary casein in the small intestinal contents is calculated to be approximately $2.49 \mathrm{mg}$, since the amount of PEG was estimated to be $30 \mathrm{mg}$ and the value for PEG: casein in the diet was 0.1 (Table 3). According to this calculation, the amount of $P$ in macropeptides of the small intestinal contents is $12 \%$ of the ingested casein-P. 
Table 4. Expt l c. Food intake, total proteolytic enzyme activities and the amount of polyethylene glycol (PEG) in the small intestinal contents, and nitrogen and phosphorus contents of fractions obtained from the small intestinal contents of rats at $2.5 \mathrm{~h}$ after ingestion of $200 \mathrm{~g}$ casein/kg (basal) diet, basal diet without fat or without starch, or casein alone

(Mean values with their standard errors for four rats/group)

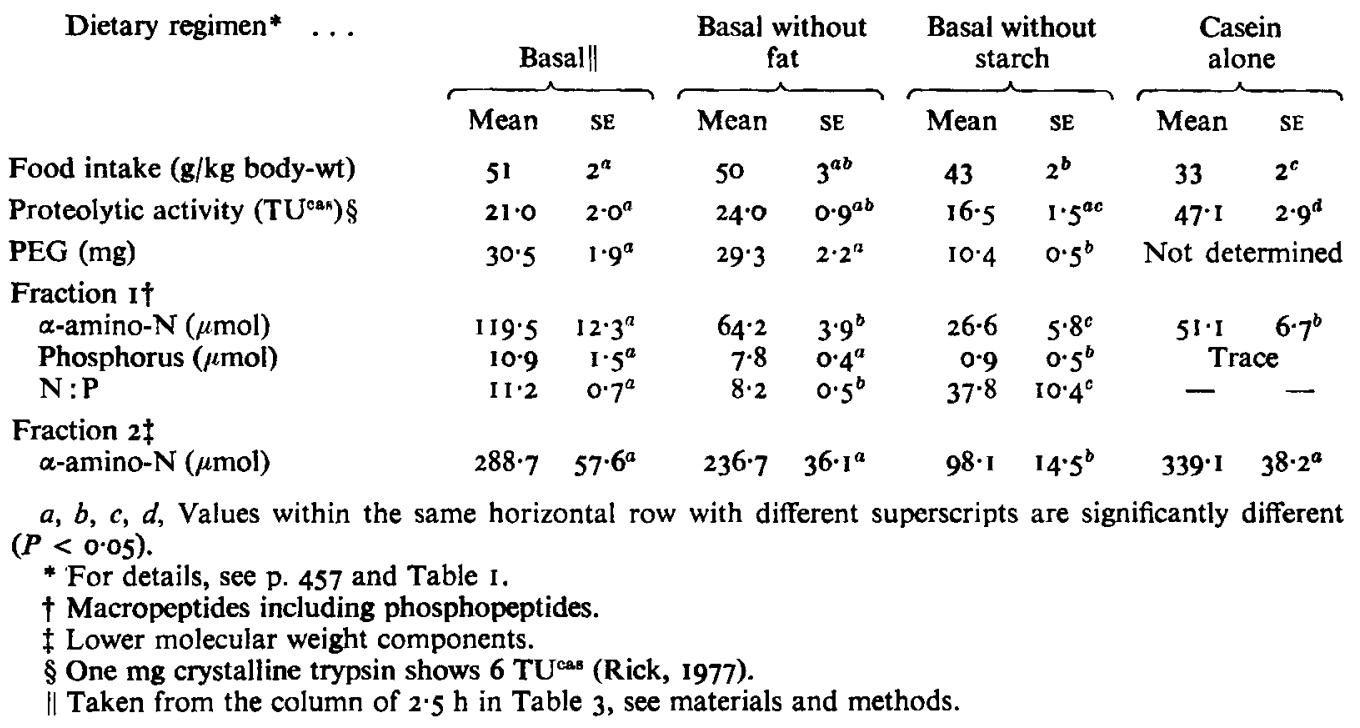

Table 5. Expt 2. Food intake and the amount of polyethylene glycol (PEG) in the small intestinal contents of rats at $2.5 \mathrm{~h}$ after ingestion of diets* containing casein, amino acid mixture, egg albumin or soya-bean protein as the protein source

(Mean values with their standard errors for four rats/group)

\begin{tabular}{|c|c|c|c|c|c|c|c|c|}
\hline \multirow[t]{2}{*}{ Dietary protein } & \multicolumn{2}{|c|}{ Casein } & \multicolumn{2}{|c|}{ Amino acid } & \multicolumn{2}{|c|}{ Egg albumin } & \multicolumn{2}{|c|}{$\begin{array}{c}\text { Soya-bean } \\
\text { protein }\end{array}$} \\
\hline & Mean & $\mathbf{S E}$ & Mean & SE & Mean & SE & Mean & SE \\
\hline Body-wt (g) & $13 I \cdot I$ & $2 \cdot 3$ & $129 \cdot 8$ & $2 \cdot 9$ & $133 \cdot 3$ & $3 \cdot 3$ & $130 \cdot 0$ & $1 \cdot 8$ \\
\hline & 50 & $3^{a}$ & 37 & $2^{b}$ & 37 & $3^{b}$ & 42 & $2^{a b}$ \\
\hline \multicolumn{9}{|l|}{$\begin{array}{l}\text { PEG (mg) } \\
\text { Portion of intestine: }\end{array}$} \\
\hline Upper $\uparrow$ & $2 \cdot 7$ & 0.4 & $3 \cdot 6$ & 0.2 & $3 \cdot 0$ & 0.2 & $3 \cdot 3$ & 0.6 \\
\hline Lower $\ddagger$ & $22 \cdot 5$ & $1 \cdot 5$ & $21 \cdot 3$ & $2 \cdot 8$ & $21 \cdot 1$ & $2 \cdot 5$ & $24 \cdot 6$ & $1 \cdot 7$ \\
\hline Total & $25 \cdot 2$ & $1 \cdot 4$ & $24 \cdot 9$ & 2.9 & $24 \cdot I$ & $2 \cdot 6$ & $27 \cdot 9$ & $I \cdot 4$ \\
\hline
\end{tabular}

If we assume as a first approximation that the amount of $P$ found in the macropeptide fraction is equivalent to that in tryptic phosphopeptides, which contain $60 \mathrm{mg} \mathrm{P} / \mathrm{g}$ (Mellander, I950), approximately $5 \mathrm{mg}$ phosphopeptides is presumed to be present in the small intestine at $\mathrm{I}-4 \mathrm{~h}$ after ingestion of the casein diet. As will be mentioned later, the occurrence of even a small amount of CPP can prevent the precipitation of Ca (Reeves \& Latour, 1958). The fact that feeding casein alone did not bring about the formation of 
Table 6. Expt 2. Soluble calcium in the small intestinal contents of rats at $2.5 \mathrm{~h}$ after ingestion of diets* containing casein, amino acid mixture, egg albumin or soya-bean protein as the protein source

(Mean values with their standard errors for four rats/group)



$a, b, c$, Values within the same horizontal row with different superscripts are significantly different $(P<0.05)$.

* For details, see p. 457.

$\uparrow$ Duodenum and jejunum.

\$ Ileum.

$\S$ (Soluble $\mathrm{Ca} / \mathrm{PEG}$ in the small intestinal content)/(Ca/PEG in diet) $\times 100$.

Table 7. Expt 2. Insoluble calcium in the small intestinal contents of rats at $2.5 \mathrm{~h}$ after ingestion of diets* containing casein, amino acid mixture, egg albumin or soya-bean protein as the protein source

(Mean values with their standard errors for four rats/group)

Dietary protein $\ldots$

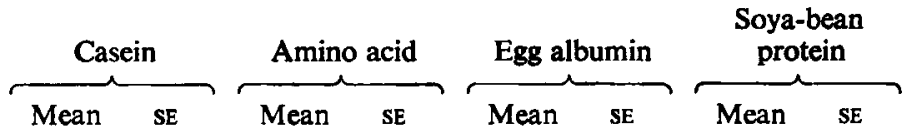

Insoluble Ca (mg)

Portion of intestine:

Upper†

Lower $\ddagger$

Total

Percentage of dietary Ca $\S$

Portion of intestine:

$\begin{array}{lllllllll}\text { Upper† } & 10 \cdot 9 & 0 \cdot 9 & 6 \cdot 8 & 1 \cdot 6 & 11 \cdot 3 & 1 \cdot 6 & 7 \cdot 4 & 2 \cdot 3 \\ \text { Lowert } & 26 \cdot 3 & 3 \cdot 9^{a} & 35 \cdot 8 & 9^{a} \cdot 4^{a b} & 41 \cdot 6 & 3 \cdot 4^{b} & 50 \cdot 6 & 3 \cdot 0^{b} \\ \text { Total } & 25 \cdot 0 & 3 \cdot 5^{a} & 31 \cdot 4 & 8 \cdot 3^{a b} & 37 \cdot 7 & 3^{b} \mathbf{2}^{b} & \mathbf{4 5 \cdot 2} & \mathbf{1} \cdot 8^{b}\end{array}$

$a, b$, Values within the same horizontal row with different superscripts are significantly different $(P<0.05)$

* For details, see p. 457.

$\uparrow$ Duodenum and jejunum.

$\ddagger$ Ileum.

$\S$ (Insoluble $\mathrm{Ca} / \mathrm{PEG}$ in small intestinal content) $/(\mathrm{Ca} / \mathrm{PEG}$ in diet $) \times 100$.

CPP suggests a requirement for other ingredients such as starch or fat or both in a casein diet. This could be partly explained by the increased activity of total proteolytic enzyme in the small intestine in response to the ingestion of casein alone.

In the present paper, it has been shown that ingestion of the casein diet resulted in a higher soluble $\mathrm{Ca}$ concentration in the small intestine, especially in the lower part than 
Table 8. Expt 2. Soluble phosphorus in the small intestinal contents of rats at $2.5 \mathrm{~h}$ after ingestion of diets* containing casein, amino acid mixture, egg albumin or soya-bean protein as the protein source

(Mean values with their standard errors for four rats/group)

\begin{tabular}{|c|c|c|c|c|c|c|c|c|}
\hline \multirow[t]{2}{*}{ Dietary protein } & \multicolumn{2}{|c|}{ Casein } & \multicolumn{2}{|c|}{ Amino acid } & \multicolumn{2}{|c|}{ Egg albumin } & \multicolumn{2}{|c|}{$\begin{array}{l}\text { Soya-bean } \\
\text { protein }\end{array}$} \\
\hline & Mean & SE & Mean & SE & Mean & SE & Mean & SE \\
\hline \multicolumn{9}{|c|}{ Soluble phosphorus (mg) } \\
\hline \multicolumn{9}{|c|}{ Portion of intestine: } \\
\hline Upper† & 0.29 & $0.05^{n}$ & 0.12 & $0.02^{b}$ & 0.12 & $0.0 I^{b}$ & 0.25 & $0.03^{a}$ \\
\hline Lower + & I. 50 & $0.11^{2}$ & 0.14 & $0.01^{b}$ & 0.28 & $0.05^{c}$ & 0.31 & $0.03^{c}$ \\
\hline Total & $1 \cdot 79$ & $0.12^{a}$ & 0.26 & $0.03^{b}$ & 0.40 & $0.05^{b e}$ & 0.56 & $0.05^{c}$ \\
\hline \multicolumn{9}{|c|}{$\begin{array}{l}\text { Percentage of dietary P\$ } \\
\text { Portion of intestine: }\end{array}$} \\
\hline Upper† & $43 \cdot 9$ & $3 \cdot 4^{a}$ & $20 \cdot 7$ & $1 \cdot 0^{b}$ & $25 \cdot 9$ & $1 \cdot 8^{b}$ & $50 \cdot 0$ & $5 \cdot 8^{n}$ \\
\hline Lower ${ }_{*}^{+}$ & $28 \cdot 0$ & $3 \cdot 2^{a}$ & $4 \cdot 6$ & $0 \cdot 7^{b}$ & $8 \cdot 2$ & $0.6^{c}$ & $8 \cdot 2$ & $0.9^{c}$ \\
\hline Total & $29 \cdot 6$ & $3 \cdot 2^{a}$ & $6 \cdot 9$ & $1 \cdot 0^{b}$ & $10 \cdot 8$ & $0.4^{c}$ & I $2 \cdot 8$ & $1 \cdot 5^{c}$ \\
\hline
\end{tabular}

$a, b, c$, Values within the same horizontal row with different superscripts are significantly different $(P<0.05)$.

* For details, see p. 457.

$\uparrow$ Duodenum and jejunum.

$\ddagger$ Ileum.

$\$$ (Soluble phosphorus/PEG in small intestinal content)/(phosphorus/PEG in diet) $\times 100$.

ingestion of diets containing egg albumin, amino acids or soya-bean protein. The reason for this phenomenon has not yet been clarified. However, from the following evidence, it can be assumed that the high solubility of $\mathrm{Ca}$ in the lower portion of the small intestine may be related to the presence of CPP, which can prevent the formation of an insoluble complex of $\mathrm{Ca}$ with phosphate. Various macropeptide species may also be formed from other dietary proteins (Naito et al. 1972). However, in the presence of these peptides, high solubility of $\mathrm{Ca}$ was not observed. A dietary amino acid mixture simulating the composition of casein also failed to increase in the amount of soluble $\mathrm{Ca}$. Therefore, it is unlikely that the amino acid composition of casein favours prevention of the formation of insoluble Ca-phosphate complex. There was no significant change in $\mathrm{pH}$ which would alter the solubility of $\mathrm{Ca}$.

It has been already confirmed in vitro that tryptic phosphopeptide of casein shows an affinity for $\mathrm{Ca}$ ions and prevents the formation of insoluble calcium phosphate from a $\mathrm{Ca}$ and phosphate mixture (Mellander, 1950; Reeves \& Latour, 1958; Shormüller \& Fresenius, 1961: Naito et al. 1972; Naito \& Suzuki, 1974). The higher soluble phosphate content in the small intestine of rats given the casein diet (Table 8 ) also corroborated these findings.

Almost all the soluble $\mathrm{Ca}$ found in the intestinal contents appeared to be ultrafiltrable (H. Naito, unpublished results).

There is increasing evidence that dietary $\mathrm{Ca}$ may be absorbed mainly in the lower part of the small intestine, at least during digestion with a normal level of Ca (Cramer \& Copp, 1959: Marcus \& Lengemann, 1962; Wasserman \& Taylor, 1976).

An elevated concentration of soluble $\mathrm{Ca}$ during food ingestion may enhance $\mathrm{Ca}$ absorption in the lower portion of the small intestine, where passive transport takes place (Lee et al. 1979) and further studies are being undertaken to investigate this possibility. 


\section{REFERENCES}

Ahrens, R. A., Wilson, J. E. Jr \& Womack, M. (1966). J. Nutr. 88, 219.

Armbrecht, H. J. \& Wasserman, R. H. (1976). J. Nutr. 69, 23.

Bennich, H., Johansson, B. \& Mellander, O. (I957). Acta Soc. Med. Upsaliensis 62, 67.

Chen, P. S., Toribara, T. Y. Jr \& Warner, H. (1956). Analyt. Chem. 28, 1756.

Cramer, C. F. \& Copp, D. H. (1959). Proc. Soc. exp. Biol. Med. 102, 5 I 4.

Hydén, S. (1955). Kgl. LantbrHögskol. Annlr 22, 139.

Lee, Y. S., Noguchi, T. \& Naito, H. (1979). Agric. biol. Chem. 43, 2009.

Lengemann, F. W. (1959). J. Nutr. 69, 23.

Marcus, C. S. \& Lengemann, F. W. (1962). J. Nutr. 77, 155.

Mellander, O. (1947). Upsala Läkarefören Förhandl 52, 107.

Mellander, O. (1950). Acra Soc. Med. Upsaliensis 55, 247.

Mellander, O. (1963). In The Transfer of Calcium and Strontium Across Biological Membranes, p. 265 [R. H. Wasserman, editor]. New York: Academic Press.

Naito, H., Kawakami, A. \& Imamura, T. (1972). Agric. biol. Chem. 36, 409.

Naito, H. \& Lee, Y. S. (1977). Ist Congr. Fedn. Asian and Oceanian Biochem. Nagoya, Japan, Abstr., p. 1 I 8.

Naito, H. \& Suzuki, H. (1974). Agric. biol. Chem. 38, 543.

National Academy of Sciences (1972). Nutrient Requirements of Domestic Animals No. 10, Nutrient Requirements of Laboratory Animals, and ed. p. 64. Washington, DC: National Academy of Sciences.

Reeves, R. E. \& Latour, N. G. (1958). Science, N.Y. 128, 472.

Rick, W. (1977). Methods of Enzymatic Analysis, p. I013 [H. U. Bergmeyer, editor]. New York: Academic Press.

Rogers, Q. R. \& Harper, A. E. (1965). J. Nutr. 87, 267.

Rosen, H. (1957). Archs Biochem. Biophys. 67, 10.

Shormüller, J. \& Fresenius, R. (1961). Z. Lebensmit. 114, 397.

Snedecor, G. W. \& Cochran, W. G. (1967). Statistical Methods, 6th ed. Ames, Iowa: The Iowa State University Press.

Wasserman, R. H. (1964). Nature, Lond. 201, 997.

Wasserman, R. H. \& Taylor, A. N. (1976). Handbook of Physiology Vol. 7 Endocrinology, p. I37 [R. O. Greep and E. B. Astwood, editors]. Washington, DC: American Physiological Society.

Zebrowska, T. (1968). Br. J. Nutr. 22, 483. 